\section{GLI3 zinc-finger gene interrupted by translocations in Greig syndrome families}

\section{Andrea Vortkamp, Manfred Gessler \& Karl-Heinz Grzeschik}

Institut für Humangenetik, Philipps-Universität, Bahnhofstrasse 7a, D-3550 Marburg, Germany

THE Greig cephalopolysyndactyly syndrome (GCPS) is an autosomal dominant disorder affecting limb and craniofacial development in humans ${ }^{1,2}$. GCPS-affected individuals are characterized by postaxial polysyndactyly of hands, preaxial polysyndactyly of feet, macroephaly, a broad base of the nose with mild hypertelorism and a prominent forehead. The genetic locus has been pinpointed to chromosome $7 \mathrm{p} 13$ by three balanced translocations associated with GCPS in different families ${ }^{3,4,19}$. This assignment is corroborated by the detection of two sporadic GCPS cases carrying overlapping deletions in 7 p13 (ref. 7), as well as by tight linkage of GCPS to the epidermal growth factor receptor gene in 7p12-13 (ref. 8). $O$ the genes that map to this region, those encoding $T$ cell receptor- $\gamma$, interferon- $\beta 2$, epidermal growth factor receptor, and Hox 1.4, a potential candidate gene for GCPS, have been excluded from the region in which the deletions overlap ${ }^{7,9}$.
FIG. 1 GCPS translocation breakpoints disrupt the GL/3 gene in $7 \mathrm{p} 13$. a, Schematic diagram depicting the presence of human chromosome-7 material retained in different lines of the human-mouse somatic cell hybrid panel ${ }^{19}$ (GM3162, human control DNA; 5387-3cl10, chromosome 7-only hybrid; IT, RoH and 1863 cell lines, GCPS translocation hybrids). $b$ - $f$, Hybridization of the somatic cell hybrid panel with different probes from $7 \mathrm{p} 13$. Control probes TG38 (ref. 15) and 5-23 (ref. 16) map within the closest intervals on the centromeric and telomeric side of the GCPS translocation breakpoints $(b)$. Probes from the GLI3 locus are ordered from centromere to telomere with pcrGli $i_{\text {orox }}(c)$ located centromeric to all three transiocations, followed by pcrGLI3 $(d)$ and pcrGL $I_{\text {dist }}(e)$ mapping between the IT/1863 and RoH breakpoints. Probe Gli $_{\text {dist }} 11$ ES5 $(f)$ is localized telomeric to all translocation breakpoints.

METHODS. Somatic cell hybrid panels ( $5 \mu \mathrm{g}$ control DNA and $15 \mu \mathrm{g}$ hybrid DNA, both digested with EcoRI) were hybridized and washed under high stringency ${ }^{17}$. Cross-hybridizing mouse fragments are marked by asterisks. Probe pcrGli3 was derived by PCR from genomic DNA with primers corresponding to nucleotides 8-27 and 592-610 of pGLI3HH-Haelll-640 (ref. 5). Probes pcrGli $i_{\text {prox }}$ and pcrGli ${ }_{\text {dist }}$ (nucleotides $98-570$ and 4,354-4,933 of the cDNA sequence ${ }^{6}$ ) were amplified after reverse transcription of adult lung total RNA (First Strand kit, Stratagene) using 20-mer primers. PCR conditions were as follows: 40 cycles of $94^{\circ} \mathrm{C}$ for $30 \mathrm{~s}, 55^{\circ} \mathrm{C}$ for $30 \mathrm{~s}$ and $72{ }^{\circ} \mathrm{C}$ for $60 \mathrm{~s}$. Probe Gli $\mathrm{i}_{\text {dist }} 11 \mathrm{ES} 5$ is a $5-\mathrm{kb}$ Sall fragment of phage Gli $\mathrm{d}_{\text {dist }} 11$ described in Fig. 2.
Here we show that two of the three translocations interrup the GLI3 gene, a zinc-finger gene of the $G L I-K$ rüppel family already localized to $7 p 13$ (refs 5,6 ). The breakpoints are within the first third of the coding sequence. In the third translocation, chromosome 7 is broken at about 10 kilobases downstream of the $3^{\prime}$ end of $G L I 3$. Our results indicate that mutations disturbing normal GLI3 expression may have a causative role in GCPS.

For a reverse genetics approach we established a humanmouse somatic cell hybrid panel subdividing the short arm of chromosome 7 into 11 intervals ${ }^{19}$. In this panel the GCPS region is defined by two hybrid clones derived from each GCPS translocation cell line retaining one or both of the translocation chromosomes and segregating the intact chromosome 7. Four random probes mapped into the shortest interval encompassing the translocation breakpoints with two probes located on either side (Fig. $1 a, b$ ). The translocation breakpoints fall within a 630-kilobase ( $\mathrm{kb})$ Notl restriction fragment identified by three of the flanking markers ${ }^{19}$.

In a parallel approach, we tested a candidate gene sequence by hybridizing a genomic fragment amplified by polymerase chain reaction (PCR) from the central part of $G L I 3$, a gene recently mapped to $7 \mathrm{p} 13$ by in situ hybridization ${ }^{6}$. This gene had been isolated by virtue of its cross-hybridization to the zinc-finger gene $G L I$, which is amplified in certain glioblastomas and represents a potential sequence-specific DNA-binding transcription factor from the GLI-Krüppel gene family ${ }^{5}$. The GL13

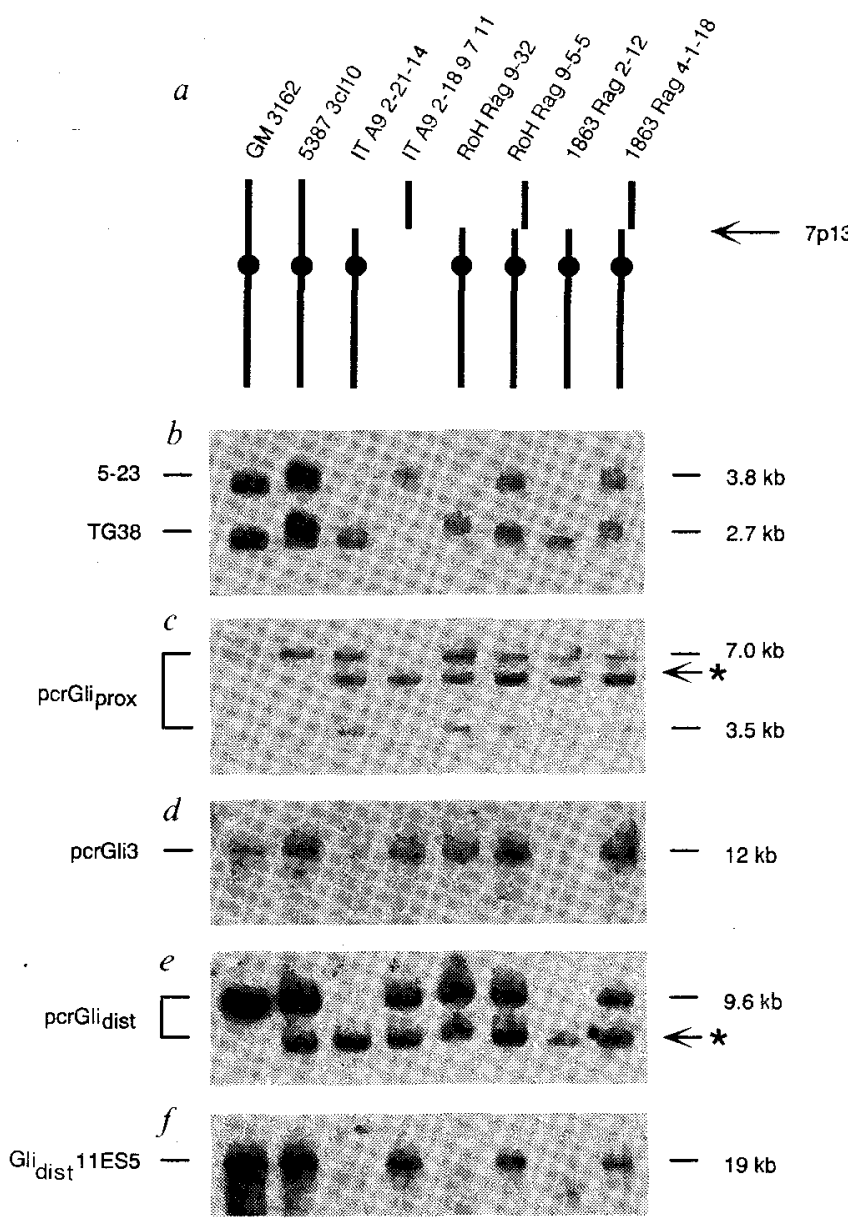



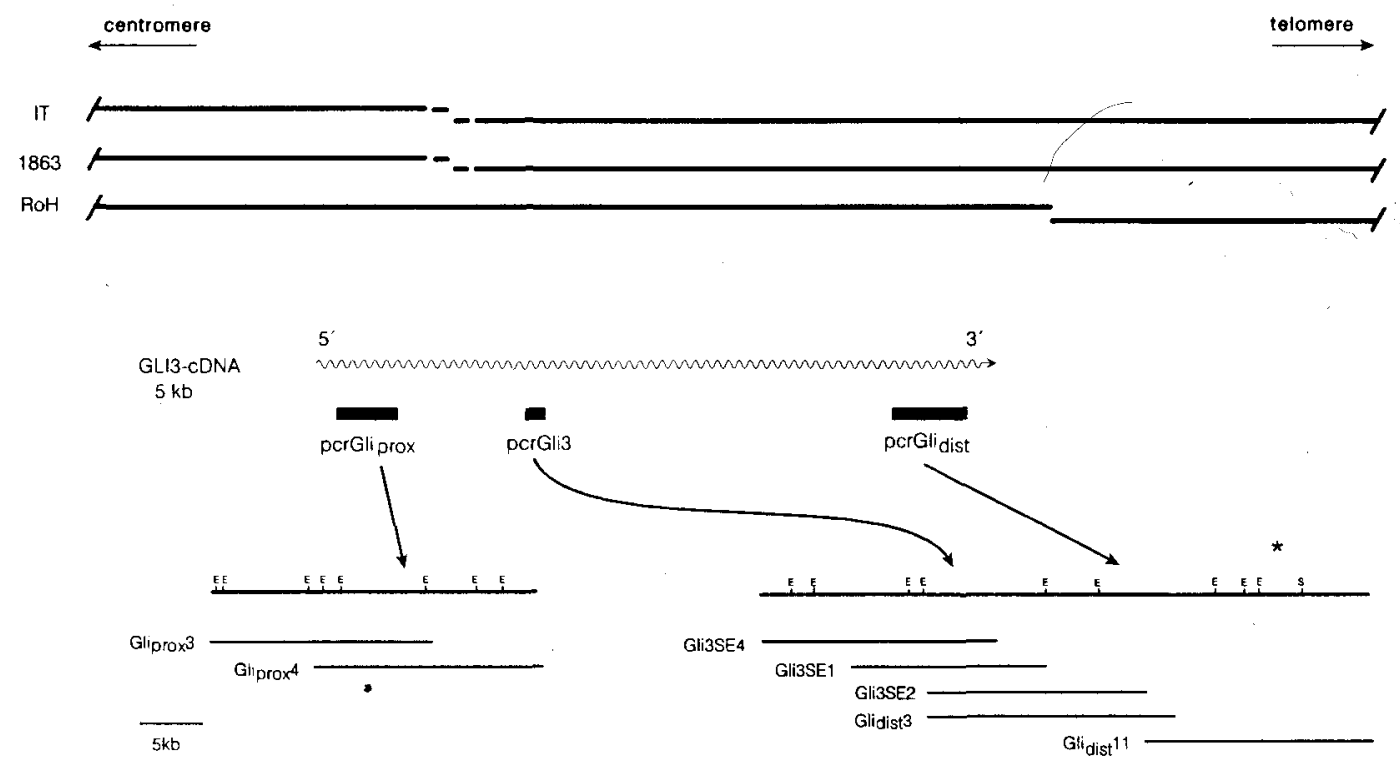

FIG. 2 A physical map of the GCPS/GL/3 region. The translocation breakpoints of the three GCPS patients are shown on the top in relation to the GL/3 CDNA sequence. The position of the PCR probes used is indicated by black boxes. A restriction map derived from genomic phage clones isolated by screening with the PCR probes or phage end fragments is drawn on a larger scale (E, EcoRl; S, Sall). The location of the RoH breakpoint spanned by
$\mathrm{Gli}_{\text {dist }} 11$ is indicated by an asterisk.

METHODS. Overlapping phage clones were isolated from a genomic $\mathrm{Mbol}$ partial digest library in EMBL3 using the PCR probes described in Fig. 1. Clone $\mathrm{Gli}_{\text {dist }} 11$ was isolated by chrosome walking with the 6-kp EcoRl/Sall end-fragment of phage $\mathrm{Gli}_{\text {dist }} 3$ subcloned into pBluescript II SK-(Stratagene). All subcloning and hybridization was according to standard procedures ${ }^{18}$. gene is expressed in tissues such as testes, myometrium, placenta, colon and lung as an 8.5-kilobase messenger RNA and the protein product (relative molecular mass, 190,000) shows sequence-specific DNA binding ${ }^{5,6}$. On our panel this probe, pcrGli3, mapped distal to the Greig translocation breakpoints in patients $1863(46, \mathrm{XY}, \mathrm{t}(3 ; 7)(\mathrm{p} 21.1 ; \mathrm{p} 13))$ and IT $(46, \mathrm{XX}$, $t(6 ; 7)(q 12 ; p 13)$ ), but proximal to the one in $\operatorname{RoH}(46, X X$, $\mathrm{t}(6 ; 7)(\mathrm{q} 27 ; \mathrm{p} 13))$ (Fig. $1 d)$. Thus, GLI3 maps very closely or may even be identical to the GCPS gene.

To define the position of the three translocation breakpoints along the $G L I 3$ gene we used pcrGli $\mathrm{i}_{\text {prox }}$ and pcrGli ${ }_{\text {dist }}$, sequences corresponding to proximal and distal segments of the $G L I 3$ complementary DNA sequence ${ }^{6}$ (Fig. 2), amplified by PCR from

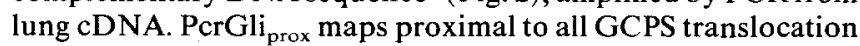
breakpoints (Fig. 1c), indicating that two of the translocations split the GLI3 gene within the first third of the coding region, thereby precluding the formation of a normal functioning protein. This also establishes the transcriptional orientation of $G L I 3$ from centromere to telomere. Probes from a $30-\mathrm{kb}$ genomic phage contig selected by pcrGli ${ }_{\text {prox }}$ did not detect the translocation breakpoints, suggesting that the $5^{\prime}$ part of this gene is spread over a large genomic distance (Fig. 2).

On the other hand, pcrGli ${ }_{\text {dist }}$, like pcrGli3, maps proximal to the RoH breakpoint and distal to the 1863 and IT breakpoints (Fig. 1e). The third translocation breakpoint thus has to be downstream of the $3^{\prime}$ end of GLI3 (Fig. 2). Analysis of five independent cDNA clones isolated from a human fetal kidney library $^{10}$ using pcrGli $_{\text {dist }}$ as probe showed no evidence for alternatively spliced transcripts in this region, which might extend to the RoH translocation breakpoint. Thus, the translocation probably falls distal to the last exon of $G L I 3$.

To map the distal translocation breakpoint, we isolated a $50-\mathrm{kb}$ phage contig, including $15 \mathrm{~kb}$ of DNA downstream of the GLI3 coding sequence. The RoH translocation breakpoint was found by hybrid mapping in a $3.5-\mathrm{kb}$ Eco RI/Sall fragment about $10 \mathrm{~kb}$ downstream of $G L I 3$ (Figs $1 f$, and 2). In this case a cis-acting element might have been brought into the neighbourhood of $G L I 3$, thereby modifying its expression. The influence of 3 '-acting domains has been well documented in variant Burkitt lymphomas, in which translocations of more than $10 \mathrm{~kb}$ downstream of the c-myc gene deregulate its expression ${ }^{11}$.

Our results support the assumption that mutations affecting only one allele of the zinc finger gene GLI3 cause the GCPS syndrome. With the potential function as a transcriptional regulator, GLI3 could well control limb and craniofacial development, perhaps through involvement in the generation of a morphogen gradient, as proposed for vertebrate limb formation ${ }^{12}$. The fact that GLI3 is widely expressed in adult tissues, with only some of these being phenotypically altered by heterozygous mutation, implies that precise control of $G L I 3$ expression is crucial only at certain developmental stages. Studies of mouse mutant extra toes $(\mathrm{Xt})^{13}$, and anterior digit deformity $(\mathrm{add})^{14}$, which are presumed to have similarities with GCPS, may reveal more about the function of GLI3. Various finger proteins, among them those from the GLI-Krüppel gene family, have key roles in Drosophila and Xenopus development. Our results provide an example of a zinc-finger gene that is mutated in a hereditary human malformation.

\footnotetext{
Received 23 Aprit; accepted 21 June 1991.

1. Greig, D. M. Edin. med. J. 33, 189-218 (1926)

2. Gollop. T. R. \& Fontes, L. R. Am. J. med. Genet. 22, 59-68 (1985).

3. Tommerup, N. \& Nielsen, F. Am. J. med. Genet. 16, 313-321 (1983).

4. Krüger, G. et al. Am. L med Genet. 32, 411-416 (1989).

5. Ruppert, J. M. et al. Molec. cell. Biol. 8, 3104-3113 (1988)

6. Ruppert, J. M. Vogelstein, B., Arheden, K. \& Kinzler, K. W. Molec. cell. Biol. 10, 5408-5415 (1990).

7. Wagner, K., Kroisel, P. M. \& Rosenkranz, W. Genomics 8, 487-491 (1990)

7. Wagner, K., Kroisel, P. M. \& Rosenkranz, W. Genomics 8, 487-491 (1990).

8. Brueton, L., Huson, S. M. Winter, R. M. \& Williams

10. Gessler, M. et al. Nature 343, 774-778 (1990).

11. Bornkamm, G. W., Pollack. A. \& Eick, D. in Cellular Oncogene Activation (ed. Klein, G.) 223-273 (Dekker, New York, 1988).

12. Eichele, G. Trends Genet, 5, 246-251 (1989)

13. Winter, R. \& Huson, M. Am. I. med Genet. 31, 793-798 (1988).

14. Pohl, T. M., Mattei, M.G. \& Rüther, U. Development 110, 1153-1157 (1990)

14. Rohl, T. M., Mattei, M.-G. \& Rüther, U. Development 110, 1153-115.

15. Rommens, J. M. et al. Am. J. hum. Genet. 43, 645
16. Jobs, A. et al. Hum. Genet. 84, 147-150 (1990).

17. Church, G. M. \& Gilbert, W. Proc. natn. Acad. Sci. U.S. A. 81, 1991-1995 (1984)

18. Maniatis, T., Fritsch, E. F. \& Sambrook, J. Molecular Cloning: A Laboratory Manual (Cold Spring Harbor Laboratory, New York, 1982).

19. Vortkamp, A. et at Genomics (in the press).

ACKNOWLEDGEMENTS. We thank N. Tommerup and L. Pelz for fibroblast cell lines 1863 and RoH, C. Croce for hybrid 5387-3c110 and S. Orkin for an aliquot of the EMBL3 library. This work was supported by a grant from the Deutsche Forschungsgemeinschaft.
} 